\title{
THE REFERENDUM AS AN INSTRUMENT TO JOIN INTERNATIONAL ORGANIZATIONS
}

\author{
Zlatka GERGINOVA \\ "Neofit Rilski" South-West University Blagoevgrad, Bulgaria \\ z_mihailova@abv.bg
}

\begin{abstract}
The article scrutinizes the referendum as an instrument to join international organizations. It analyzes the interaction of the participants for achieving unanimity and consensus, not differences or attempts to impose a certain opinion. A conclusion is drawn that through direct democracy the citizens take responsibility for the future development of the state.
\end{abstract}

\section{Keywords: referendum, democracy, international organizations}

\section{Introduction}

The formation of an international organization is based on common principles that are adopted voluntarily by all party cofounders. In elaborating the Statute or Rules of the existence and work of the organization the norms of the international law as well as the rules of domestic law of the founding countries are observed. In drawing up the Act for establishing the international organization there are discussed and formulated the goals and objectives of the organization as well as the forms and methods of its existence and cooperation between members. Thus, at the highest level it is highlighted the "unity of the international and domestic legitimacy". [1] This is, on the one hand, because of the growing influence of international law on the legislation of individual countries, especially in the period of a general globalization and on the other hand, because of the pursuit of individual sovereign states to unify their legislation with accepted international norms, among which a primary place is taken by human rights.

In this respect, the example of the European Union in recent years, especially regarding the two enlargements of 2004 and 2007, is especially significant. The so-called "concurrence of wills" [2] of the participants is one that allows the "adaptation" of the interstate legislation to the joint appearances of the participants in the international organization. Naturally, what is important is the interaction and willingness of participants to achieve consensus and opportunity for synergy, to achieve consensus on the set issues to be resolved rather than highlighting the differences and the attempt to impose an opinion from a position of strength. Probably without differences it would not be possible to continue with the formation of a new international organization or accepting new members into the organization. The rallying unit is the will, the desire for cooperation in the name of common goals. "In other words, entities agree on the content of the norm and assigning it to the relevant obligatory force." [3]

The preamble of the UN Charter, the Statute of the International Court of Justice, and the Vienna Convention on the Law of Treaties of 1969 focus on the sources of international law [4]. They are considered 
as an official foreign legal form of the existence of international legal norms, customs, treatiess and rulemaking decision of international organizations. Treaties and customs are adopted as generally recognized sources of international law. They create norms that are established in society. And as auxiliaries judgments and doctrines of qualified professionals may be applied, although this is disputed, but their legal force is determined by the founding act of the organization. In the EU the implementation of the resolutions of international organizations is adopted.

\section{Main tasks of the international governing}

The international governing is faced with the following tasks:

- Ensuring safety for all citizens;

- preventing the consequences of interdependence that allows placing the interests of one party over the interests of another;

- preventing systemic crises globally, including climate change and financial crises;

- ensuring universal respect of the rights of peoples and individuals.

No country alone can cope with the resolution of all these complex tasks. For this reason, there is a growing number of international organizations and associations, and at the same time their meaning is growing as well. This is probably explained by the fact that there is a constant "increase of global problems whose solution is only possible with the combined efforts of the states." [6]

The implementation of the main tasks is a continuous activity and goes through radical changes in the minds of the majority. It is not enough to adopt one norm of the statutes of any international organization as binding. There is a need of continuous work for the clarification of its nature, its importance for the society and for the individual. It must achieve that level at which every member of society should realize the need to respect the norm because it works for the benefit of the public, whose part they are from. Here the combined efforts of many (mostly non-governmental) organizations, the media, educational institutions and politicians to achieve the common good, as cliché as it sounds, should enter into action.

As "special subjects of international law" the international organizations are "carriers of certain interests and are called upon to defend them." [7] Even if there appears to be a controversy among members of the organization or disagreement on specific issues, all together are obliged to work for the implementation of common tasks according to the Statute of the organization. The strength and effectiveness of the organization is in the mutual agreement among the members. Proof of this is the Declaration on the Principles of International Law of the 25th session of the UN General Assembly in 1970. On the other hand, the Vienna Convention on the Law of Treaties of 1969 could not come into force for a long time because it was originally adopted by only half the countries.

The attitude towards the international treaties is not equal in different states. In France, for example, international treaties have a priority over the laws of the country. The basic law of Germany accepts norms of international law to be part of the federal law. The constitution of the Netherlands is often changed to align the state law with the international one. [8]

In this regard, it should be shown appreciation to the growing role of the public in decision-making at national and supranational level. An example of this is the implementation of direct democracy in Switzerland and Liechtenstein with the known frequent referenda at local and state level. A confirmation of the growing role of voters in making important government decisions are the carried out in France and the Netherlands in 2005 referenda on the Treaty Establishing a Constitution for the 
EU, whose negative result affected the acceptance of a common basic union law. Whether the referendum will establish itself as an instrument of accession to international organizations is too early to say. In all cases, however, countries have the legal basis of the right of international treaties, legally formed in the Vienna Convention on the Law of Treaties of 1969. [9]

For the Swiss Confederation the conclusion of international treaties is the responsibility of the Bundesrat and increasingly leads to the exercise of democratic rights of the Swiss. The Swiss constitutional and legal order regarding the conclusion of international treaties protects the democratic rights of participation of the parliament and the people. The direct democracy at the conclusion of international treaties in any other country is not as well developed as in the Confederacy.

\section{Bilateral relations of Switzerland with other states}

The bilateral relations of Switzerland with other countries are governed by international law. The growing intensity of these relationships leads to an increase in international legal norms that impact on the attitude of the Swiss people. The expectations of citizens in the democratic legitimacy of international law also increased. These processes are reflected in the reform of the Federal Constitution of 1999, as "the right of participation of Parliament in the conclusion of international treaties is institutionalized and the political rights in the sphere of state treaties are adapted to these in the field of national legislation." [10]

The Federal Constitution of 1999 strengthened the foreign policy position of the Parliament. Article 166, para. 1 secured the foreign policy competences of the Federal Assembly exclusively on the constitutional level. According to para. 2 of the same article the Swiss parliament "approves the international legal treaties; exception are treaties for whose conclusion based on a law or international treaty the Bundesrat is competent." [11] The Bundesrat "prepares an annual report to the Federal Assembly for all executed by it ... state treaties." [12]

The most important means of securing foreign policy inside the domestic one remains the direct participation of the people. With the reform of citizens' rights the scope of application of the optional referendum regarding international treaties has significantly been expanded. According to Art. 141a (adopted on a referendum on February 9, 2003, effective August 1, 2003): "1. If the decision for approving the international legal treaty is subject to a mandatory referendum, the Federal Assembly may adopt amendments to the Constitution that serve to implement the treaty in the decision for approval.

2. If a decision for approving the international legal treaty is subject to an optional referendum, the Federal Assembly may adopt legislative changes that serve to implement the treaty in the decision for approval.“" [13]

The reform aims to make a significant parallelism with the legal referendum and subject all international treaties containing important legally defining provisions to a facultative referendum. The same is true for treaties that require the issuance of federal laws.

Article 141, para. 1, letter d), number 1 of the Swiss Federal Constitution states that international treaties which are not limited by time and are permanent, are subject to a facultative referendum. Most of the treaties concluded by Switzerland contain an explicit clause for interruption or the subject of the treaty makes it clear that it is concluded for a fixed period or contains a possibility for interruption.

The largest number unlimited by terms and permanent agreements are border treaties signed by the Confederation with its neighboring countries. They are permanent 
because the parties to the treaty proceed from the indisputability of the agreed limits. As permanent are discussed both the UN Covenant on Economic, Social and Cultural Rights and on Civil and Political Rights, approved by the Federal Assembly on December 13, 1991, which are subject to the facultative referendum with an unlimited term and permanent treaties set in the previous constitution of the state.

The permanent treaties reflect the desire of the parties under them to commit themselves for an indefinite period of time with a state treaty. However, of course, the parties may agree to terminate a treaty or, within a treaty change, to add a clause for its termination. The unilateral termination of a treaty is possible only in exceptional cases, when "one of the parties thereto does not comply with essential contractual obligations or when significant circumstances, which provided the basis for the conclusion of the ttreaty, have an unpredictable twist. Without one of these reasons the unilateral termination of a treaty would constitute a breach of a treaty.“ [14]

\section{Conclusion}

According to Rico Hoffmann: "The revised general concept of the Swiss foreign policy, modern understanding of neutrality and independence, as well as more open stance on international affairs in 1990s resulted in the Confederacy - despite some restraint participation in the European integration being actively engaged in various policy areas in international organizations today and represented in the most important institutions of international politics. “ [15]

Naturally one could rightly pose the following question: Is the referendum always the best way to implement the accession of a country to an international organization? The answers range from YES to NO by passing through multiple reflections on the awareness of voters about the importance of state participation in the relevant organization, about the positives and negatives for the country from the longterm participation in the work of the organization, about the retention or loss of autonomy in decision-making and many others. It is known that voters often decide how to vote based on moral motives or according to their party affiliation rather than on the basis of good knowledge of the matter. In this sense, a referendum would also be "vitiated". On the other hand, however, in modern society it is becoming increasingly unacceptable to talk about the poor awareness of voters despite the frequently criticized role of the media. It is not right to impose a party bias on voters either, or a temporary adjustment to display a positive or negative attitude towards the current governing of the state, especially when it comes to the accession of the country to an international organization. Voters should be given an opportunity to freely express their will, even when - as it is shown by some repeatedly conducted referenda in Switzerland on the same issue the result of the referendum is negative. Thus, for example, Swiss voters decided their country to join the world organization of the UN in 2002 after a negative referendum in 1986. This indicates that the direct democracy is an expression of the people's will and the people's will must be decisive in the state. Through direct democracy citizens take responsibility for the future development of the state and it is not only their right but it is also a duty. However, no matter how different the notion of democracy is in different countries around the world, there is the possibility to teach ourselves democracy by increasing the level of political literacy.

\section{References}

[1] Лукашук И. И. Международное право. Общая часть. Москва, Волтерс Клувер, 2005 , с. 5.

[2] Пак там, с. 25 и сл. 
[3] Пак там.

[4] The issue has been scrutinized later - Лукашук, 2005, с. 29-31.

[5] По Лукашук, 2005, с. 12-13.

[6] Лукашук, 2005, с. 121.

[7] Лукашук, Цит. съч., 2005, с. 37.

[8] Пак там, с. 276 и сл.

[9] ВИЕНСКА КОНВЕНЦИЯ за правото на договорите, Ратифицирана с Указ № 503 на Държавния съвет от 12.02.1987 г. - ДВ, бр. 14 от 1987 г., Издадена от Министерство на външните работи, обн., ДВ, бр. 87 от 10.11.1987 г., в сила за България от 21.05.1987 г. (VIENNA CONVENTION on the Law of Treaties, ratified by Decree № 503 of the Council of State on 12.2.1987 - SG. 14 of 1987 issued by the Ministry of Foreign Affairs, Prom. SG. 87 of 10.11.1987, in force for Bulgaria since 21.05.1987)

[10] http://www.parlament.ch/D/Suche/Seiten/geschaefte.aspx?gesch_id=20093256, last retrieved 01.08.2014.

[11] Bundesverfassung der Schweizerischen Eidgenossenschaft vom 18. April 1999, in Kraft seit dem 1. Januar 2000. http://www.admin.ch/opc/de/classifiedcompilation/19995395/index.html am 29.12.2013.

[12] Art. 48a Abs. 2 des Regierungs- und Verwaltungsorganisationsgesetzes; SR 172.010, http://www.admin.ch/opc/de/classified-compilation/19970118/index.html, last retrieved 03.10.2014.

[13] Bundesverfassung der Schweizerischen Eidgenossenschaft vom 18. April 1999, in Kraft seit dem 1. Januar 2000. http:/www.admin.ch/opc/de/classifiedcompilation/19995395/index.html am 29.12.2013.

[14] http://www.parlament.ch/D/Suche/Seiten/geschaefte.aspx?gesch_id=20093256, last retrieved 01.08.2014.

[15] Rico Hofmann, Die Schweiz und Internationale Organisationen - Unterschiede in Repräsentation und Engagement, Masterarbeit, 2004. 